\title{
EXPLORING OF MULTI MATHEMATICAL REPRESENTATION CAPABILITY IN PROBLEM SOLVING ON SENIOR HIGH SCHOOL STUDENTS
}

\author{
Nizaruddin, Muhtarom, Yanuar Hery Murtianto \\ University PGRI Semarang, Indonesia \\ E-mail: nizaruddin@upgris.ac.id, muhtarom@upgris.ac.id, yanuarheri@upgris.ac.id
}

\begin{abstract}
The students' multi-mathematical representation capability in problem solving is very important and interesting to discuss, specifically for problems in the two-variable linear equation system. Data was collected from 48 students using written tests and in-depth interviews with selected participants. The research findings showed that few students are using three representations namely symbolic-verbal-table representation, and symbolic representation, however most of the students are using three representations namely symbolic - verbal - images representation, and two representations namely symbolic - verbal representations, and the rest used symbolic representation. In the use of verbal representation, some students had difficulty composing words and all students encountered difficulties in the translational process from symbolic representation and verbal representation to other types of representation. The ability to understand concepts and relationships between mathematical concepts was found to be a necessary condition for the achievement of multi-mathematical representation capability. It is therefore recommended that teachers use a variety of different types of representation, such as verbal, tables and images, to enhance students' understanding of the material.
\end{abstract}

Keywords: multiple representations, problem solving, two-variable linear equation system.

\section{Introduction}

Mathematical representation ability is important in understanding mathematics, both when students are solving mathematical problems and when they need to communicate their solutions to others, and it is also a form of attitude in mathematics. Problem-solving abilities are related to metacognition (Muhtarom, Juniati \& Siswono, 2017), as well as mathematical representation abilities. Moreover, representation can be presented in the form of images, symbols, and signs (notation), which are all forms of mathematical concepts (Vergnaud, 1997). Representation is a kind of configuration process to present something in a different situation which involves identification, selection and the delivery of ideas (Goldin \& Kaput, 1996; Romberg \& Kaput, 1999; Seeger et al, 1998). Everything that students do to externalize and show their work is called representation (Kalathil \& Sherin, 2013). Hwang, Chen, Dung, \& Yang (2007) conclude that good representational skills are the key to gaining the right solutions to solve problems.

Every problem can be solved by using different types of representation (Gagatsis \& Elia, 2004 ) and this means there is a close relationship between the problem and its representations. Mathematical representations that are associated with the simultaneous use of different methods, such as symbols, diagrams, tables, verbal statements, figures and so on, are known as multiplerepresentations (Brenner et al., 1997). The use of multiple representations allows one to explore mathematical concepts in various ways, and emphasizes that there may be more than one possible mathematical process for producing a solution to a problem (Romberg \& Kaput, 1999). 
NIZARUDDIN, MUHTAROM, Yanuar Hery MURTIANTO. Exploring of multi mathematical representation capability in problem solving on senior high school students

\section{PROBLEMS \\ OF EDUCATION \\ IN THE $21^{\text {st }}$ CENTURY Vol. 75, No. 6, 2017 \\ 592}

Keller \& Hirsch (1998) stress that the use of multiple representations is an advantage, since it avoids limitation to a single type of representation and builds something new, which is clearer and more useful for the problem-solving process. Thus, there are several functions of multiple representation: 1) the different representations complement each other; 2) the interpretation of other representations is limited; 3 ) the process of constructive understanding is enhanced (Ainsworth, 2006). This means that the use of multiple representations is recommended by many mathematical educators. Similarly, the mathematics community supports the idea that students can interpret mathematical concepts through the experience of multiple representations (Janvier, 1987; Sierpinska, 1992).

The use of different representations can make concepts more accessible and enjoyable for the student. Romberg \& Kaput (1999) and Hiebert \& Carpenter (1992) state that the use of multiple representations helps students to learn by using their own thinking and learning habits. Nizaruddin et al, (2017) offers the view that game-based learning can improve students' problem-solving skills, and furthermore it has the potential to develop the representation skills needed for solving mathematics problems. It is generally recognized that learning facilitates students in accommodating their thoughts to develop their own knowledge schemes (Muhtarom, Yanuar \& Sutrisno, 2017). Therefore, a learning process that uses two representations is better than a process using only a single representation (Bransford \& Schwartz, 1999; Ainsworth, 2006). Thus, an understanding of multiple representations can support students' comprehension of mathematical concepts, as well as anticipating the fallacy of concepts in mathematics. This means that the ability to understand concepts and relationships between mathematical concepts is a necessary condition for the achievement of multi-mathematical representation capability.

In Indonesia, to date there has been little research on multiple-representation capability; existing studies tend to discuss only the types of representation used by students (Santia, 2015; Tyas, 2016; Muhamad, 2017) and do not offer views on the multiple-representation capability of students or the translation process from one representation to another. Therefore, it is interesting to research students' multi-mathematical representation in problem solving, especially among students in Indonesia. The purpose of this current research is to determine the multi-mathematical representation capability of students in solving mathematical problems, specifically two-variable linear equation problems.

Research on multiple representations is an important topic to address because the identification of multiple representation capability can be used for developing teaching material. In addition, the importance of multiple representations in this research can be used to improve students' creative thinking. This research will explore multiple representation capability, specifically in mathematical problem solving in two-variable linear equation problems, observing the following thought processes: procedure-oriented, process-oriented, math objectoriented and concept-oriented.

\section{Research Methodology}

\section{General Background}

This research is qualitative and explores multi-mathematical representation capability in problem solving, specifically in two-variable linear equation problems. The results of the research can be used as the basis for developing teaching material for the two-variable linear equation system based on multiple representations so as to improve students' creative thinking ability, especially in Indonesia.

\section{Sample}

The participants in this research were 48 Senior High School students from the Madrasah Aliyah Darun Najah Senior High School in the Margoyoso District of Pati Regency during 
the academic year 2017/2018. The selection of participants was based on the following considerations: 1) the students had already been given sufficient material that they were expected to be able to complete a two-variable linear equation mathematics problem, 2) the participants selected were considered to possess good communication skills enabling them to express the process used for solving the problem, 3) in problem solving, the participants used a number of different kinds of representation. A trial of the research instrument was conducted on May 30, 2017. From the results of the trial, it was seen that the problem could be solved using various types of representation. The test results were then analyzed based on validity and reliability to determine the feasibility of the problem as a research instrument. This research involved participants who were class XI students. In the initial stage, the students were given a written test. In this research, the written test was taken by 48 prospective participants consisting of 5 male students and 43 female students. The selection of research subjects was also based on a review of the students' mathematics grades.

\section{Instrument and Procedures}

The instrument used in this research was a written test on problem solving and a guided interview based on the problem solving task to explore the multiple-representation capability of students. Prior to use, the instrument was first validated by three validators who are experts in mathematics education, and was declared eligible to be used for obtaining research data. The written test instrument was as follows: "A two-variable linear equation system has a finite set $\{3.3\}$. If the first variable coefficient is an even number and the second variable coefficient is an odd number, make a two-variable linear equation example! Also show the steps used to solve the problem using your own choice of representations". The data was collected in two stages. The first stage was the written test, as described above, which was held on July 14, 2017 at 7 a.m. in the classroom of XI IPA and at $8.40 \mathrm{a} . \mathrm{m}$. in the classroom of XI IPS. The second phase was to conduct interviews with selected subjects. The interviews were conducted based on an agreement between the researcher and the research scientist. The details of the interviews are presented in Table 1 below:

\section{Table 1. List of interviews.}

\begin{tabular}{lllll}
\hline No & Date & Participant's Code & Time & Location \\
\hline 1 & 28 July 2017 & DP & 1 p.m. & School \\
\hline 2 & 28 July 2017 & FA & 2 p.m. & School \\
\hline 3 & 31 July 2017 & MN & 10 a.m. & School \\
\hline 4 & 31 July 2017 & RI & 11 a.m. & School \\
\hline
\end{tabular}

\section{Data Analysis}

In the first stage of the data collection, students were asked to solve a two-variable linear equation problem using various representations that they were familiar with. Based on the data obtained from this test, a data analysis and reduction were then performed to obtain a detailed description of the students' multi-mathematical representation capabilities in problem solving. Next, four suitable participants who fulfilled the necessary criteria were selected to participate in semi-structured interviews which focused on their multiple-representation capabilities in solving a two-variable linear equation problem. The four participants were RI (participant with code RI) who used three representations, namely symbolic - verbal - image representations; FA (participant with code FA) who used three representations, namely symbolic - verbal - tables, DP who used two representations, namely symbolic - verbal, and MN (participant with code $\mathrm{MN}$ ) who used only symbolic representation in solving the mathematics problem (see Table 1). Next, the data was analyzed and validated using the triangulation method, where data from the 
NIZARUDDIN, MUHTAROM, Yanuar Hery MURTIANTO. Exploring of multi mathematical representation capability in problem solving on senior high school students

PROBLEMS

OF EDUCATION

IN THE $21^{\text {st }}$ CENTURY Vol. 75 , No. 6, 2017

594

results of the triangulation was valid participant data for providing a description of the students' multi-mathematical representation capabilities.

\section{Results of Research}

Table 2 presents a clear description of the results of the data analysis of the 48 students. From this, the types of representation used by students for solving the problem can be identified, namely: symbolic - verbal - image representations, symbolic - verbal - table representations, symbolic - verbal representations, and symbolic representation. The percentage of students using three representations, namely symbolic - verbal - table representation was $8.33 \%$, the use of symbolic - verbal - image representation was $37.5 \%$, those using two representations namely symbolic - verbal representation was $45.83 \%$ and those using only one representation was $8.33 \%$.

Table 2. Representation used by participants.

\begin{tabular}{|c|c|c|c|c|}
\hline Representation & $\begin{array}{l}\text { Type of representa- } \\
\text { tion }\end{array}$ & Participant's Code & $\%$ & $\begin{array}{l}\text { Selected partici- } \\
\text { pants with code* }\end{array}$ \\
\hline \multirow[t]{2}{*}{ Three representations } & $\begin{array}{l}\text { Symbolic - verbal - } \\
\text { images }\end{array}$ & $\begin{array}{l}\mathrm{DN}, \mathrm{RD}, \mathrm{NA}, \mathrm{ES}, \mathrm{SY}, \mathrm{RI}^{*}, \mathrm{DR} \\
\mathrm{PR}, \mathrm{UN}, \mathrm{AK}, \mathrm{DI}, \mathrm{MF}, \mathrm{RM}, \mathrm{ET} \\
\mathrm{CN}, \mathrm{NL}, \mathrm{MN}, \mathrm{MA}\end{array}$ & 37.5 & RI \\
\hline & $\begin{array}{l}\text { Symbolic - verbal - } \\
\text { table }\end{array}$ & $\mathrm{FA}^{*}, \mathrm{MK}, \mathrm{NN}, \mathrm{BR}$ & 8.33 & FA \\
\hline Two representations & Symbolic - verbal & $\begin{array}{l}\text { SW, ZN, NS, K, IA, RW, NDS, } \\
\mathrm{DP}^{*}, \mathrm{NM}, \mathrm{CL}, \mathrm{RM}, \mathrm{ZY}, \mathrm{AP}, \mathrm{PN} \text {, } \\
\mathrm{HN}, \mathrm{ZN}, \mathrm{PL}, \mathrm{MD}, \mathrm{EF}, \mathrm{NS}, \mathrm{IK} \\
\text { VN }\end{array}$ & 45.83 & DP \\
\hline One representation & Symbolic & $\mathrm{ME}, \mathrm{MN}^{*}, \mathrm{ND}, \mathrm{AS}$ & 8.33 & MN \\
\hline
\end{tabular}

Participant RI solved the two-variable linear equation problem using 3 representations, namely symbolic - verbal - image representations. When answering using symbolic and verbal representations, participant RI was able to answer correctly but when answering using image representation there were mistakes in the answer. The representation and thought process of RI's problem solving is shown clearly in Table 3.

Table 3. Analysis of the results of the participant with code RI.

\begin{tabular}{|c|c|c|c|}
\hline \multirow{2}{*}{$\begin{array}{l}\text { Thought } \\
\text { Process }\end{array}$} & \multicolumn{3}{|c|}{ Representation } \\
\hline & Symbolic & Verbal & Image \\
\hline $\begin{array}{l}\text { Proce- } \\
\text { dure- ori- } \\
\text { ented }\end{array}$ & $\begin{array}{l}\text { Able to manipulate symbols to } \\
\text { complete the results compre- } \\
\text { hensively and systematically. }\end{array}$ & Able to use the right procedure. & $\begin{array}{l}\text { Unable to use the proper proce- } \\
\text { dure to obtain the image form of } \\
\text { the problem. }\end{array}$ \\
\hline $\begin{array}{l}\text { Process- } \\
\text { oriented }\end{array}$ & $\begin{array}{l}\text { Able to interpret the meaning of } \\
\text { written symbols. }\end{array}$ & $\begin{array}{l}\text { Able to apply the process well } \\
\text { with few mistakes. }\end{array}$ & $\begin{array}{l}\text { Unable to understand or apply the } \\
\text { problem-solving process properly. }\end{array}$ \\
\hline $\begin{array}{l}\text { Math } \\
\text { object- } \\
\text { oriented }\end{array}$ & $\begin{array}{l}\text { Able to operate the relevant } \\
\text { mathematical symbols. }\end{array}$ & $\begin{array}{l}\text { Able to use words in under- } \\
\text { standing the mathematical } \\
\text { objects. }\end{array}$ & $\begin{array}{l}\text { Unable to interpret images in } \\
\text { problem solving. }\end{array}$ \\
\hline $\begin{array}{l}\text { Concept- } \\
\text { oriented }\end{array}$ & $\begin{array}{l}\text { Able to relate procedures and } \\
\text { processes applied to symbolic } \\
\text { representation in mathematical } \\
\text { concepts and able to identify } \\
\text { concepts used in mathematical } \\
\text { operations. }\end{array}$ & $\begin{array}{l}\text { Able to relate procedures and } \\
\text { processes applied to verbal } \\
\text { representation in mathematical } \\
\text { concepts and able to identify } \\
\text { concepts used in mathematical } \\
\text { operations. }\end{array}$ & $\begin{array}{l}\text { Unable to relate procedures } \\
\text { and processes applied to image } \\
\text { representation in mathematical } \\
\text { concepts but able to identify } \\
\text { concepts used in mathematical } \\
\text { operations. }\end{array}$ \\
\hline
\end{tabular}


NIZARUDDIN, MUHTAROM, Yanuar Hery MURTIANTO. Exploring of multi mathematical representation capability in problem solving on senior high school students

The participant with the code FA solved the two-variable linear equation problem using 3 representations, namely symbolic - verbal - image representations. When answering with the use of symbolic representation, the participant FA was able to answer correctly but when answering using verbal and table representations, there were a number of mistakes in the answer. For a clearer picture, the representation and thought process of the participant FA's problem solving are presented in Table 4.

Table 4. Analysis of the results of the participant with code FA.

\begin{tabular}{llll}
\hline \multicolumn{1}{c}{$\begin{array}{c}\text { Thought } \\
\text { Process }\end{array}$} & \multicolumn{1}{c}{ Symbolic } & \multicolumn{1}{c}{ Representation } \\
Procedure- & $\begin{array}{l}\text { Able to manipulate symbols } \\
\text { to complete the results } \\
\text { compriented } \\
\text { atically. }\end{array}$ & $\begin{array}{l}\text { Unable to use the procedure } \\
\text { appropriately. }\end{array}$ & $\begin{array}{l}\text { Table } \\
\text { Unable to use the proper proce- } \\
\text { dure to complete the results. }\end{array}$ \\
\hline $\begin{array}{l}\text { Process- } \\
\text { oriented }\end{array}$ & $\begin{array}{l}\text { Able to interpret the meaning } \\
\text { of written symbols. }\end{array}$ & $\begin{array}{l}\text { Unable to implement the } \\
\text { problem-solving process } \\
\text { properly. }\end{array}$ & $\begin{array}{l}\text { Unable to understand and } \\
\text { implement the problem solving } \\
\text { process. }\end{array}$ \\
\hline $\begin{array}{l}\text { Math object- } \\
\text { oriented }\end{array}$ & $\begin{array}{l}\text { Able to operate the relevant } \\
\text { mathematical symbols. }\end{array}$ & $\begin{array}{l}\text { Able to use words in under- } \\
\text { standing the mathematical } \\
\text { objects. }\end{array}$ & $\begin{array}{l}\text { Unable to interpret the problem } \\
\text { in the form of mathematical } \\
\text { tables. }\end{array}$ \\
\hline $\begin{array}{l}\text { Concept- } \\
\text { oriented }\end{array}$ & $\begin{array}{l}\text { Able to relate procedures } \\
\text { and processes applied to } \\
\text { symbolic representation in } \\
\text { mathematical concepts and } \\
\text { able to identify concepts used } \\
\text { in mathematical operations. }\end{array}$ & $\begin{array}{l}\text { Unable to relate procedures } \\
\text { and processes applied to } \\
\text { verbal representation in } \\
\text { mathematical concepts but } \\
\text { able to identify concepts used } \\
\text { in mathematical operations. }\end{array}$ & $\begin{array}{l}\text { Unable to relate procedures and } \\
\text { processes applied to precise ta- } \\
\text { ble representation and unable to } \\
\text { identify and operate mathemati- } \\
\text { cal concepts. }\end{array}$ \\
\hline
\end{tabular}

The participant with code DP solved the two-variable linear equation problem using two representations, namely symbolic - verbal representations. When answering with the use of symbolic representation, it appeared that the participant was able to use the relevant symbols, namely variables $\mathrm{x}$ and $\mathrm{y}$, and able to complete the process well even though the procedure used was not yet complete. The participant was able to interpret the symbols used, able to relate the procedures and processes applied to symbolic representation in the mathematical concepts, and able to identify the concepts used in the mathematical operations. Participant DP was able to answer correctly and was aware of the mistakes made in the completion process using verbal representation because of his understanding of the characteristics of the two-variable linear equation system. The representation and thought process of participant DP's problem-solving are presented in Table 5.

Table 5. Analysis of the results of the participant with code DP.

\begin{tabular}{lll}
\hline \multicolumn{1}{c}{$\begin{array}{c}\text { Thought } \\
\text { Process }\end{array}$} & \multicolumn{1}{c}{ Symbolic } & \multicolumn{1}{c}{ Verbal } \\
\cline { 2 - 3 } $\begin{array}{l}\text { Procedure- } \\
\text { oriented }\end{array}$ & $\begin{array}{l}\text { Able to manipulate symbols in the results } \\
\text { although still incomplete. }\end{array}$ & $\begin{array}{l}\text { Able to use appropriate and systematic proce- } \\
\text { dures. }\end{array}$ \\
\hline $\begin{array}{l}\text { Process- } \\
\text { oriented }\end{array}$ & $\begin{array}{l}\text { Able to interpret the meaning of written } \\
\text { symbols. }\end{array}$ & Able to apply the process correctly. \\
\hline $\begin{array}{l}\text { Math object- } \\
\text { oriented }\end{array}$ & $\begin{array}{l}\text { Able to operate the relevant mathematical } \\
\text { symbols. }\end{array}$ & $\begin{array}{l}\text { Able to use words in understanding the math- } \\
\text { ematical objects used. }\end{array}$ \\
\hline & $\begin{array}{l}\text { Able to relate procedures and processes ap- } \\
\text { plied to symbolic representation in mathemat- }\end{array}$ & $\begin{array}{l}\text { Able to relate procedures and processes applied } \\
\text { to verbal representation in mathematical concepts } \\
\text { and able to identify concepts used in mathemati- } \\
\text { Concept- } \\
\text { oriented }\end{array}$ \\
$\begin{array}{l}\text { ical concepts and able to identify concepts } \\
\text { cal operations. }\end{array}$ \\
\hline
\end{tabular}

PROBLEMS

OF EDUCATION

IN THE $21^{\text {st }}$ CENTURY

Vol. 75, No. 6, 2017

595 
NIZARUDDIN, MUHTAROM, Yanuar Hery MURTIANTO. Exploring of multi mathematical representation capability in problem solving on senior high school students

\section{PROBLEMS \\ OF EDUCATION \\ IN THE $21^{\text {st }}$ CENTURY \\ Vol. 75, No. 6, 2017 \\ Table 6. Analysis of results of participant with code MN.}

\begin{tabular}{ll}
\hline Thought Process & Representasi Simbolik Symbolic Representation \\
\hline Procedure-oriented & $\begin{array}{l}\text { Unable to manipulate symbols to complete the results comprehensively and systemati- } \\
\text { cally. }\end{array}$ \\
\hline Process-oriented & Able to interpret the meaning of written symbols. \\
\hline Math object-oriented & Able to operate the relevant mathematical symbols. \\
\hline Concept-oriented & $\begin{array}{l}\text { Unable to relate processes and procedures applied to symbolic representation in math- } \\
\text { ematical concepts but able to identify concepts used in mathematical operations. }\end{array}$ \\
\hline
\end{tabular}

The participant with the code MN solved the problem of a two-variable linear equation system using symbolic representation. This is evident from the use of variables $\mathrm{x}$ and $\mathrm{y}$. Participant MN was unable to use the proper procedures and processes because there was still a large amount of verbal representation. The participant was essentially able to interpret the symbols used but was unable to relate the procedures and processes applied to the symbolic representation in mathematical concepts though able to identify the concepts used in mathematical operations. The representation and the problem-solving thought process of the participant with code DP are presented in Table 6.

\section{Discussion}

The results of this research show that students essentially have the ability to solve problems using various types of representation. It was found that only $8.33 \%$ of students solved the problem presented using only a single type of symbolic representation. Students who had a high level of independence were seen to use a number of different types of representations, unlike other students who used only a single type of representation to solve the problem. In addition, the students' understanding of mathematical concepts was reflected in the greater number of representations used to solve the problem (Brenner et al., 1997). However, it should be noted that some of the students still encountered difficulties in the process of transferring the use of different types of representation, for example, in the beginning they used symbolic representation, then verbal or image representation (other types of representation). This is in line with the research of Gagatsis \& Elia (2004) which concludes that students encounter numerous difficulties in changing from symbolic representation (algebra) into verbal representation. An investigation by Janvier (1987) shows how a successful transfer between one type of representation and another varies depending on the nature of the relationship between the chosen representations. Thus, in order to use different representations, students require knowledge of the subject matter as well as knowledge about representation because not all material can be presented using all types of representation.

This provides an overview of the importance of the ability to understand concepts and relationships between mathematical concepts, which are the main requirements for achieving multi-mathematical representation capability. The fact that some students were incapable of creating a proper representation for understanding the problem is believed to be because teachers, especially in Indonesia, often use only symbolic representation for solving mathematical problems, including two-variable linear equation problems. It should be recognized that the use of different representations makes concepts more accessible and enjoyable for students, and for this reason, solving the same problem using different representations or multiple representations shows better results than the use of a single representation (Hiebert \& Carpenter 1992; Romberg \& Kaput, 1999). Ainsworth (2006); Bransford \& Schwartz (1999); and Keller \& Hirsch (1998) state that two representations are better than one because they avoid the limitations of a single type of representation and build a new, clearer representation for the problem-solving process. This means that the ability to understand concepts and relationships between mathematical 
concepts is a necessary condition for the achievement of multi-mathematical representation capability, and multiple-representation ability itself is able to support students in understanding each different mathematical concept and anticipating mistakes in understanding mathematical concepts.

\section{Conclusions}

Students tend towards the use of symbolic representation rather than other types of representation in solving two-variable linear equation problems. When students use verbal representation, they are inclined to have difficulty in composing words while in image or table representation they are unable to solve the problem correctly. Based on these facts, we can conclude that the choice of representation used to solve a problem greatly affects the students' answers because the use of a particular type of representation requires knowledge of the mathematical concept as well as an understanding of the representation itself. Suggestions for further research include an exploration of the students' thought process in transitioning between different types of representation, such as verbal representation to symbolic representation or vice versa.

\section{References}

Ainsworth, S. (2006). DeFT: A conceptual framework for considering learning with multiple representations. Learning and Instruction, 16 (3), 183-198.

Bransford, J. D., \& Schwartz, D. L. (1999). Chapter 3: Rethinking transfer: A simple proposal with multiple implications. Review of Research in Education, 24 (1), 61-100.

Brenner, M. E., Mayer, R. E., Moseley, B., Brar, T., Durán, R., Reed, B. S., \& Webb, D. (1997). Learning by understanding: The role of multiple representations in learning algebra. American Educational Research Journal, 34 (4), 663-689.

Gagatsis, A., \& Elia, I. (2004). The Effects of Different Modes of Representation on Mathematical Problem Solving. International Group for the Psychology of Mathematics Education. Retrieved from http://emis.ams.org/proceedings/PME28/RR/RR171_Gagatsis.pdf.

Goldin, G. A., \& Kaput, J. J. (1996). A joint perspective on the idea of representation in learning and doing mathematics. In: L. P. Steffe, P. Nesher, P. Cobb, G. A. Goldin, \& B. Greer (Eds.), Theories of mathematical learning (pp. 397-430). Hillsdale, NJ: Lawrence Erlbaum.

Hiebert, J., \& Carpenter, T. P. (1992). Learning and teaching with understanding. In D. A. Grouws (Ed.), Handbook of research on mathematics teaching and learning: A project of the National Council of Teachers of Mathematics (pp. 65-97). New York: Macmillan.

Hwang, W.-Y., Chen, N.-S., Dung, J.-J., \& Yang, Y.-L. (2007). Multiple Representation Skills and Creativity Effects on Mathematical Problem Solving using a Multimedia Whiteboard System. Journal of Educational Technology \& Society, 10 (2). Retrieved from http://www.jstor.org/stable/ jeductechsoci.10.2.191.

Janvier, C. (1987). Representation and understanding: The notion of function as an example. In C. Janvier (Ed.), Problems of representation in the teaching and learning of mathematics (pp. 67-71). Hillsdale, NJ: Erlbaum.

Kalathil, R. R., \& Sherin, M. G. (2013). Role of students' representations in the mathematics classroom. In International Conference of the Learning Sciences: Facing the Challenges of Complex Realworld Settings (p. 27). East Sussex: Psychology Press.

Keller, B. A., \& Hirsch, C. R. (1998). Student preferences for representations of functions. International Journal of Mathematical Education in Science and Technology, 29 (1), 1-17.

Muhamad, N. (2017). Pengaruh Metode Discovery Learning untuk Meningkatkan Representasi Matematis dan Percaya Diri Siswa. (The Influence of the Discovery Learning Method on Improving Students' Mathematical Representation and Confidence). Jurnal Pendidikan UNIGA, 10 (1), 9-22.

Muhtarom., Murtianto, Yanuar Hery \& Sutrisno. (2017). Thinking Process of Students with HighMathematics Ability (A Study on QSR NVivo 11-Assisted Data Analysis). International Journal of Applied Engineering Research, 12 (17), 6934-6940. 
NIZARUDDIN, MUHTAROM, Yanuar Hery MURTIANTO. Exploring of multi mathematical representation capability in problem solving on senior high school students

\section{PROBLEMS \\ OF EDUCATION \\ IN THE $21^{\text {st }}$ CENTURY \\ Vol. 75 , No. 6, 2017}

598

Muhtarom., Juniati, Dwi., \& Siswono, T.Y.E. (2017). Exploring Beliefs in a Problem-Solving Process of Prospective Teachers' With High Mathematical Ability. Global Journal of Engineering Education, 19 (2), 130-136.

Nizaruddin, Muhtarom, \& Sugiyanti. (2017). Improving Students' Problem-Solving Ability in Mathematics through Game-Based Learning Activities. World Transactions on Engineering and Technology Education, 15 (2), 102-107.

Romberg, T. A., \& Kaput, J. J. (1999). Mathematics worth teaching, mathematics worth understanding. In E. Fennema, \& T. A. Romberg (Eds.) Mathematics classrooms that promote understanding (pp. 3-18). Mahwah, NJ: Lawrence Erlbaum Associates.

Santia, I. (2015). Representasi Siswa SMA dalam Memecahkan Masalah Matematika Berdasarkan Gaya Kognitif. (High School Students' Representation in Solving Mathematics Problems Based on Cognitive Style). JIPM (Jurnal Ilmiah Pendidikan Matematika), 3 (2). Retrieved from http://ejournal.ikippgrimadiun.ac.id/index.php/jipm/article/view/505.

Seeger, F. (1998). Representations in the mathematics classroom: Reflections and constructions. In F. Seegers, J. Voigt, \& U. Waschescio (Eds.), The culture of the mathematics classroom (pp. 308343). New York: Cambridge University Press.

Sierpinska, A. (1992). On understanding the notion of function. The concept of function: Aspects of epistemology and pedagogy, 25, 23-58.

Tyas, W. H., Sujadi, Imam., Riyadi. (2016). Representasi Matematis Siswa dalam Menyelesaikan Masalah Matematika pada Materi Aritmatika Sosial dan Perbandingan ditinjau dari Gaya Kognitif Siswa Kelas VII SMP Negeri 15 Surakarta Tahun Ajaran 2014/2015. (Students' Mathematical Representation in Solving Social Arithmetic Mathematics Problems and a Comparison with the Cognitive Style of Class VII Students from the No. 15 Surakarta State Middle School Academic Year 2014/2015). Jurnal Elektronik Pembelajaran Matematika, 4 (8), 781-792.

Vergnaud, G. (1997). The nature of mathematical concepts. In P. Bryant (Ed.), Learning and Teaching Mathematics. East Sussex: Psychology Press.

Received: October 12, 2017

Accepted: December 18, 2017

\begin{tabular}{|ll} 
Nizaruddin & M.Si., Lecturer, Department of Mathematics Education, Faculty of Mathematics \\
& Education and Natural Science, University PGRI Semarang, Indonesia. \\
& Email: nizaruddin@upgris.ac.id \\
& Web: http://orcid.org/0000-0002-1166-6006 \\
Muhtarom & M.Pd., Lecturer, Department of Mathematics Education, Faculty of Mathematics \\
& Education and Natural Science, University PGRI Semarang, Indonesia. \\
& Email: muhtarom@upgris.ac.id \\
& Web: https://www.researchgate.net/profile/Muhtarom_Muhtarom \\
\hline Yanuar Hery Murtianto & M.Pd., Lecturer, Department of Mathematics Education, Faculty of Mathematics \\
& Education and Natural Science, University PGRI Semarang, Indonesia. \\
& Email: yanuarheri@upgris.ac.id \\
Web: https://www.researchgate.net/profile/Yanuar_Hery_Murtianto
\end{tabular}

